\title{
Video Based Learning as a Media for Teaching English during Pandemic Covid-19
}

Joko Prayudha S.,

University of Bengkulu

Email: jokoprayudha@gmail.com

\section{ARTICLE INFO \\ Article History: \\ Accepted: April 2021 \\ Approved: June 2021 \\ Published: June 2021 \\ Key Words: \\ Video Based Learning, \\ Media, English Language \\ Teaching, Pandemic Covid-19}

DOI: $10.35719 /$ jlic.v3i1.53

\begin{abstract}
The COVID-19 pandemic has stopped the face-to-face learning process becoming online learning. This provides a very different learning experience when compared to faceto-face learning. There are many obstacles faced by students, one of which is the lack of understanding of the material when the online material explanation takes place. However, to overcome this problem, there are many ways that teachers can do, one of which is by implementing video-based learning. Video-based learning means providing material by using video to deliver material. Therefore this study tries to see the benefits of using video-based learning in learning English during the implementation of online learning. This research used the library research by collecting and conducting in-depth literature studies from various research journals. As a result, several studies explain that learning with video has been proven to be able to help teachers and students effectively in encouraging the teaching and learning process in the classroom and can provide a better understanding of the material during online learning.
\end{abstract}

\section{INTRODUCTION}

At the end of 2019 the world was shocked by the presence of a new virus called corona, or better known as covid 19. In Indonesia this virus developed from March 2020 to its peak in August. Prayudha (2021) said that in March 2020 covid 19 developed in Indonesia. However, this virus is still spreading today. This virus makes everyone in the world panic and beset by worries. People who live in cities and villages (Syah, 2020) are affected by this 


\section{JLIC}

outbreak. Many aspects of life have been brought to a standstill due to the COVID-19 pandemic. One aspect that is also influential is in the education sector. This situation affects the world system, including the education system (Schleicher, 2020). However, not only big companies in the world, the Indonesian government also shows its contribution and concern for the education system (Basilaia \& Kvavadze, 2020). Many school learning processes have stopped due to this pandemic. To overcome this problem, the government and teachers have made a policy where the face-to-face learning process is switched to online learning. Previously they studied and taught in class, but now everything is online (Daniel, 2020: 1) (Krishnapatria, 2020: 1-2). The government should close all schools, universities and other public places to avoid the spread of Covid 19 (Bhamani et al, 2020). All schools in the world announced that they were closed due to the COVID-19 pandemic (Nasr, 2020). The online teaching and learning process means maximizing the use of internet access in the learning process in electronic devices such as smartphones, laptops, tablets, computers (e learning) (Stern, 2018: 1) (Atmojo \& Nugroho, 2020: 51-53). As it is known that the spread of this virus is so fast that it is necessary to limit human activities in bulk or better known as physical distancing. This method is done in order to minimize the spread of the corona virus, especially in the educational environment so that learning is needed that can minimize the spread of this virus, so that online learning is implemented.

Online learning does not require students and teachers to meet directly in learning, but to use or utilize technology to carry out the learning process. Prayudha (2021) said that online learning is the best alternative in the midst of the COVID-19 pandemic. Changes in the learning system have made all schools use distance learning (Rasmitadila et al, 2020). So it can be concluded that online learning in the midst of a pandemic is an innovation that can be used as an alternative learning to continue the teaching and learning process. However, changing face-to-face learning methods to online learning does not necessarily make learning better. There are many weaknesses in implementing online learning. One of these problems is the lack of understanding of students understanding the learning material when the material is given by their teacher online. This has become a serious problem in addition to other problems that arise in online learning. Lack of 
understanding the learning material will have a negative impact on students. They will not be able to master the learning material so they will tend not to be creative and passive when learning. Many students feel very bored when implementing online learning. So it is necessary to have interesting learning to attract students' interest in learning even though learning is online.

Prayudha (2021) explains that an online learning system like this will certainly bring up various kinds of obstacles that will be faced by both teachers and students in the implementation of online learning. With this online learning method, it will provide a new atmosphere and challenge for both students and teachers in carrying out online learning. This challenge is for those who are not used to using the application in learning so that students' interest in learning is reduced. In a study conducted by Prayudha (2021) revealed that there are obstacles and problems that occur when online learning is carried out, such as; (1) lack of understanding of how to use learning applications, (2) limited internet quota, (3) incomplete learning resources/materials, (4) poor communication, and (5) decreased learning motivation during online learning. In other words, the application of online learning also raises new problems faced by students and teachers. The teacher as the holder of the control of the learning process has a very important role for the smooth running of learning. The teacher is the key holder in learning so that to realize good learning the teacher must be able to set learning strategies so that students do not feel bored while studying and can understand the material being taught well even in online learning situations.

There are many ways that teachers can do to attract students' interest in learning during online classes. One way that teachers can use is to use video-based learning. Video-based learning means the learning process uses various forms of video in providing understanding of the material to students. Videos can help students by visualizing how something works and show information and details difficult to explain by text or static photos. In addition, videos can attract students' attention, thus motivating them and engaging them to increase their collaboration. Using videos thus can lead to better learning outcomes. Moreover, video can support different learning styles, specifically students who are 'visual learners' (Yousef, et. Al., 2014). The combination of online learning using learning videos seems to create a better atmosphere 


\section{JLIC}

and interest and motivation for students than learning that does not use media at all. Therefore, the use of learning videos in the teaching and learning process of English will be more fun and effective in helping students understand the learning material. Ronchetti (2010) said that video offers several intuitive advantages where video technology is seen as more suitable in conveying material for students.

According to Wang (2015), there are three goals of teaching English with video materials: The first is to facilitate the development of EFL learners' language skills. It means that the video can provide a lot of information for the learners, get their attention to focus on the material in the video, and improve their comprehensive linguistic competence. The second is to cultivate students' competence of intercultural communication. When the video is presented in the classroom, it does not only give information about the language, but the learners can also learn about the culture of English native speakers. Then, it can support the learners' communicative competence in English. The third is to cultivate students' aesthetic values and ability to appreciate English videos of Artistic values. Based on the explanation above, this study provides information about video based learning in teaching English, it is expected to present valuable information for the teachers, especially EFL teachers about some ways that they can implement when teaching English by using video.

\section{METHODS}

This research was designed in descriptive qualitative research. The data was collected from some related literature about the implementation of video based learning in teaching English. Then, data were analyzed in three steps; data reduction, data display, and conclusion/verification. Firstly, data that relates to the utilize of video based learning in EFL classroom was collected. At the point, the data is displayed based on the parts of video and strategies of utilizing video. Then, the information is presented based on the roles of video and techniques of employing video. Both of the components were expected to represent great roles of video in EFL classroom and few ways that can be applied by the EFL teachers in instructing by conveying video. The last, some conclusions were drawn to attest more meaningful ways in deploying video in the classrooms. 


\section{RESULTS AND DISCUSSION \\ Videos of Learning and Development}

Learning videos are media that present audio-visual messages, language, procedures, application theory to help understanding learning theory (Slamet, 2012). One tool that is often seen as an important resource in addressing pedagogical knowledge acquisition is the use of video in the classroom. Indeed, practice videos have become a popular resource in teacher education (Tina, 2013). Video-based learning has been a major focus of the educational research community for the past two decades (Meg, 2016). Video-based learning for young children is very important, because these children have difficulty understanding the symbolic meaning of two-dimensional images (Gabrielle, 2018).

So what is meant by "learning media is the use of materials and tools in learning, or merely learning media can be understood as media used in the learning process and objectives. In this case, the media is used as a tool that can help educators and students in preparing and receiving subject matter" (Berk, 2009; Matijević, 2014). Examples of instructional media are as follows: books, pictures, LCDs, torso, undead, audio, video, slides, videos and others. In general, the media can be categorized into three types such as visual media (picture or form), audio media (radio, audio cassettes) and audiovisual media (Video, TV and Computers). Video is a recording of an image or a real object that is accompanied by sound or often referred to as audiovisual media that displays both images and sound. This media is very often used in the teaching and learning process because it can foster students' interest in learning, where students can simultaneously listen and see things even though objects that are seen and heard are not directly from the primary source, but through intermediary media such as TV, laptops, computers, or mobile phone.

Videos offer the opportunity to observe the teaching of specific subjects and specific approaches to teaching and learning over a long period of videos in a limited amount of time (Thomas, 2016). According to Rhonchetti (2010), the main advantage of using video in learning is the ability to help students work by bridging the gaps provided by their absence during study, supporting regular students by providing opportunities to recover lost lectures, helping students who have difficulty with language lectures. oral, and gives 


\section{$J \mathbf{L I C}$}

students the goal of reviewing critical passages and examining their notes.

Nowadays, video-based learning is increasingly being used in education because it is easier to create and store it online (Vincent, 2014). According to Stem (2019), if we accept the importance of starting to work on video to facilitate learning from teachers with the right method for educating, then educator leaders will start using video. Videos can help students understand and remember information, improve their cognitive processes and improve their learning performance (Pei-lan-lei, 2015). In addition, according to Sara Routarinne, the video method has proven effective for teacher training in three ways, namely to reflect on pedagogical events and develop specific analytical skills, to focus on student thinking and bridge theory and practice, namely to align pedagogical recommendations for actual classroom practice.

According to Vincent Hoogerheide the results of the research show that explaining to others through video can be an effective learning activity compared to reviewing it. New technologies such as video conferencing classes bring new ways for teachers to collaborate with students and encourage the development of strategies that are more consistent with new technology (Lydie, 2014).

\section{The effectiveness of instructional videos on learning activities and outcomes}

Technology is a tool that helps students and educators to achieve specific educational goals. Advances in ICT have contributed to the emergence of new literacy practices (Aynur 2014). One of these practices is a digital video project prepared by students. In this project students are involved in the assignment of preparing a video in which they practice the language they are learning. The implementation of these projects has a number of benefits for learners.

Hafner and Miller (Aynur 2014) show that video projects provide a social context in which learners are able to interact with one another as well as experiment with various digital video technologies to make meaningful personal multimodal artifacts. Furthermore, through these projects, the ability of students to use digital video technology to capture and play their own performances as well as performances from others will facilitate 
reflection on their language learning. As emphasized by Nikitina (2009), with the help of video projects, students languages have the opportunity to practice the target language in a more meaningful way and to develop useful strategies that can facilitate their learning process. In addition, Masats, Dooly, and Costa (2009) regard video making as an effective learning tool because it involves students in a cooperative project which is an excellent opportunity to integrate all students in the classroom. (Aynur, 2014).

According to Wang's (2017) research, the presence of instructors in the form of instructional videos or instructional videos positively affects learners' perceptions of learning and satisfaction. This is in line with Shoufan's research (Iris 2015) which states that searching for educational videos and video producers improves the quality of content and learning outcomes. In addition, performance and satisfaction with texts were higher with mobile groups, while video was more influential for individual learning (Iris, 2015). Ian (2010) stated that studying video games can contribute not only to increased understanding of learning mechanisms but also can offer a new approach to teaching spatial skills.

Lydie (2014) in her research states one of the greatest instructional benefits of video conferencing includes enhanced communication skills, and presentation skills among students. Instead of just reading textbooks and other printed material, video conferencing allows students to interact with real people outside of one's country. In this capacity, video conferencing allows students to learn from engaging speakers and educational tours without even leaving their class. As a result, students learn about other cultures and state events rather than reading outdated textbooks, seeing pictures or hearing from teachers about countries. Through video conference teachers can bring the outside world into the classroom in a very real way. Thatcher (2000) reports that animation can increase understanding and generate interest in DNA replication studies. Mc Clean (2007) also reports that students who undergo lectures using animation have a better resistance to learning molecular biology than students who do not undergo lectures without animation.

Learning videos have provided many benefits for humans, especially students. Learning videos are usually integrated with online applications that can be accessed using the internet. These 


\section{JLIC}

applications provide services for sharing and learning via smartphones, so that time and space limitations can be overcome. Of course this is good news for millennial students who cannot be separated from smartphones.

Recently, distance learning has become more and more popular and is in great demand by students. Now learning and studying through online is no longer impossible. There are even several online learning applications and sites that provide certificates and diplomas for those who have passed the learning process, such as HarukaEdu. With distance learning, students do not need to leave the comfort of their home to study and of course learning can take place more effectively with interactive learning videos. With smartphones, learning videos can be accessed anytime and anywhere as long as they have internet access, so this can be beneficial for students who have long distance access to participate in learning activities.

Several research results also show that learning activities that use video-based learning or video learning show positive results in increasing interest, motivation to learn and cognitive abilities of students. Even learning videos can be a task that can increase students' understanding of the learning material taught by the teacher and can foster self-confidence when students present the task in front of their peers.

The results of Paivio's (Kartika 2013) research on dual coding theory which revealed that long-term memory contains two separate but interdependent coding mechanisms, namely verbal and visual. Two codes are better than one code. Verbal information will be better when accompanied by visual displays (pictures or animation). When information is received verbally and visually, the likelihood of getting it back increases because if one source of memory is lost the other will still be available. O'day (2007) states that animation provides better long-term memory resistance than still images in cell biology courses, as well as Stith (2004) states that certain processes in cell biology material are easier to present through animation than by using animation. still image.

Apart from students, learning videos are also useful for educators. With instructional videos, educators no longer have to explain at length the concept of learning, especially difficult concepts such as the digestive system, the circulatory system and the nervous system, which students cannot understand when only 
using two-dimensional media. Educators can also be more creative in developing skills in the field of technology and can assess the portion that is lacking in the learning media they make.

\section{CONCLUSION}

Although the use of video in many EFL classrooms is not something new anymore, but more positive responds are still addressed by the students. Based on the research results, it can be concluded that teaching using video in English classes especially due online learning can help students in the teaching and learning process. Students find it easier to understand the material being taught with the help of attractive visual images. Then also the use of video-based learning as a media for distance learning has a positive effect and can improve cognitive abilities, improve learning performance, develop students' interest and motivation, and students have a better understanding of the concepts of English lessons being taught.

\section{REFERENCES}

Atmojo, A. E. P., \& Nugroho, A. (2020). EFL Classes Must Go Online! Teaching Activities and Challenges during COVID-19 Pandemic in Indonesia. Register Journal, 13(1), 49-76. https://doi.org/10.18326/rgt.v13i1.49-76

Bal-Gezegin, B. (2014). An investigation of using video vs. audio for teaching vocabulary. Procedia-Social and Behavioral Sciences, 143, 450-457.

Basilaia, G., \& Kvavadze, D. (2020). Transition to Online Education in Schools during a SARS-CoV-2 Coronavirus (COVID-19) Pandemic in Georgia. Pedagogical Research, 5(4). https://doi.org/10.29333/pr/7937.

Berk, R. A. (2009). Multimedia teaching with video clips: TV, movies, YouTube, and mtvU in the college classroom. International Journal of Technology in Teaching \& Learning, $5(1), 1-21$.

Chan, L. K., Patil, N. G., Chen, J. Y., Lam, J. C., Lau, C. S., \& Ip, M. S. (2010). Advantages of video trigger in problem-based learning. Medical teacher, 32(9), 760-765.

Daniel, S. J. (2020). Education and the COVID-19 pandemic. PROSPECTS. https://doi.org/10.1007/s11125-020-09464-3. 
Hadijah, S. (2016). Teaching by using video: Ways to make it more meaningful in EFL classrooms. Proceedings of ISELT FBS Universitas Negeri Padang, 4(2), 307-315.

Herron, C., Cole, S. P., Corrie, C., \& Dubreil, S. (1999). The effectiveness of a video-based curriculum in teaching culture. The Modern Language Journal, 83(4), 518-533.

Irawati, D. (2016). Supporting student's English speaking achievement using Video. IJEFL, $1(1)$, 45-6o.

Lopez-Alvarado, J. (2017). Teaching English using video materials: design and delivery of a practical course. International Journal of Research and Education, 2(3), 1.

Matijević, M. (2014). Learning in the e - environment: New media and learning for the future. Libellarium, 7(1), 93-103.

McNulty, A., \& Lazarevic, B. (2012). Best practices in using video technology to promote second language acquisition. Teaching English with technology, 12(3), 49-61.

Milosevic, D. (2017). Using video materials in English for technical sciences: a case study. New developments in ESP teaching and learning research, 15-30.

Prayudha. S, Joko. (2021). Students' Problems Face In Online Learning Amidt Pandemic Covid-19. Acitya: Journal of Teaching \& Education.

Prayudha.S, Joko. (2021). Efektivitas Komunikasi Terhadap Proses Belajar dalam Pembelajaran Online. Dawuh: Dakwah \& Communication Islamic Journal. 2(1), P.33-40.

Reimers, F. (2020). Supporting the Continuation of Teaching and Learning During Covid 19 Pandemic. OECD Journal.

Reychav, I. \& Wu, D. 2015. Mobile Collaborative Learning: The Role of Individual Learning in Groups Through Text and Video Content Delivery in Tablets: Journal Computers in Human Behavior.50(4: 520-534.

Ronchetti, M. (2010). Using Lecture Video Makes Lessons More Interactive: Journal Teacher Education. 5(2): 45-58.

Routarinne, S. \& Ylirisku, S. 2012. Video Card Game as a Learning Design for Teacher Education: Journal Social and Behaviour Science. 45(6): 370-380.

Sablić, M., Mirosavljević, A., \& Škugor, A. (2020). Video-based learning (VBL) - past, present and future: An overview of the research published from 2008 to 2019. Technology, Knowledge and Learning, 1-17. 


\section{Joko Prayudha S.}

Shih, R. C. (2010). Blended learning using video-based blogs: Public speaking for English as a second language students.Australasian Journal of Educational Technology, 26(6).

Sihem, M. S. (2013). Using video techniques to develop students' speaking skill (Master's thesis).

Spence, I. \& Feng, J. 2010. Video Games and Spatial Cognition: Journal American Psychological Association. 14(2): 110-121.

Stempleski, S., \& Arcario, P. (1992). Video in Second Language Teaching: Using, Selecting, and Producing Video for the Classroom. Teachers of English to Speakers of Other Languages (TESOL), Inc., 1600 Cameron St., Suite 300, Alexandria, VA 22314.

Stern, J. (2018). Introduction to Online Teaching and Learning. International Journal of Science Education, 3, 1-10. https://doi.org/10.1002/9781118784235.eeltvo6b

Wamnebo, W., Hanapi, H., Bugis, R., \& Handayani, N. (2018). Students' Speaking Skill in Oral Descriptive Text by Using Video at Tenth Grade in SMA Negeri 1 Namlea. Jurnal Jupiter, 16(2), 98.

Williams, R. T., \& Lutes, P. (2007). Using video in the ESL classroom. Takamatsu University Journal, 48, 1-13. 